\title{
PARAMETRIC STUDY OF SQUARE REINFORCED CONCRETE COLUMNS CONFINED BY CARBON FIBER REINFORCED POLYMER UNDER UNIAXIAL LOAD
}

${ }^{\star}$ Basim M. Talib1

\author{
Hayder A. Mehdi ${ }^{1}$
}

1) Civil Engineering Department, College of Engineering, Mustansiriyah University, Baghdad, Iraq

\begin{abstract}
This paper studies the effects of the behavior of normal strength square concrete (NSC) columns confined by carbon fiber-reinforced polymer (CFRP) sheets. Six reinforced concrete columns of dimensions (100mm $\times 100 \mathrm{~mm} \times 1200 \mathrm{~mm}$ ) have been casted and tested, those samples have been subjected to uniaxial compression load (eccentricity $=0.5 \mathrm{~b}$ ) up to failure. Included the study the impact of three parameters which are the CFRP distribution (5 strips and fully wrapping), column slenderness ratio $(40,30)$ and steel reinforcement ratio $(\rho=0.0113,0.0314,0.0678)$. Those results showed high improvements in the columns' load capacity of cracking and ultimate load for all the columns.
\end{abstract}

Keywords: $R C$ Columns, Carbon Fiber Reinforced Polymer (CFRP), uniaxial load, Ductility.

\section{Introduction}

Compression column elements possibly support various structures, such as the floor slabs and bridge decks, and may play the role of piles or piers. The columns differ in the physical shape according to their applications in the situation, even though they're usually either rectangular or circular for simplifying the construction, RC columns strengthened by FRP wraps (or jackets) are now widely accepted with the continuous development of concrete technology due to their great corrosion resistance and the ease of application. Strengthening the columns of the concrete with the jackets of the FRP proved highly efficient in the enhancement of the axial load capacity and ductility [1, 2, 3, 4]. The confinement of the FRP results in increasing the lateral pressure on column that prevents the expansion of the concrete and results in causing the tri-axial stress field development in confined column. The confined concrete ductility and axial strength is increased with increasing the lateral pressure, resulting in increasing the compressive strength of the concrete and the increase of strain at which concrete crushes $[2,4$, 5].

The FRP jackets' confinement effectiveness is dependent upon a variety of the parameters, which are, concrete type, steel reinforcement, FRP jackets' thickness (amount of the layers) and the conditions of loading and stiffness $[2,5,6]$. The confinement of the FRP is of a higher effectiveness for the circular columns compared to it for the rectangular or the square columns. This results from the fact that the lateral concrete expansion under the compression has been confined uniformly in circular column, in contrast to the rectangular column, in which the confinement is concentrated at corners instead of

*Corresponding Author: basimmtalib@gmail.com 
being concentrated over the whole perimeter [2, $3,7,8]$.

The confinement can be applied in multiple fiber directions, and FRP confining has resistance in both circumferential and axial directions.

\section{Literature Review and Research Significant}

The columns may be strengthened for the purpose of increasing axial, flexural and shear capacities for various reasons, like the confinement lack, eccentric loading, accidental impacts, seismic load, and corrosion [2]. In the applications of the area, the majority of the columns aren't under the optimal concentric load. This results in the production of nonuniform confining stress as a result of strain gradient, in turn reducing the column's effectiveness [9]. Wang and Parvin (2001) [9] have discovered that the FRP wrap has been of a high effectiveness in the strengthening of the eccentrically loaded square columns, and that eccentricity had resulted in diminishing the capacity of the axial load as well as the corresponding axial deflections. Similar notes have been observed as well by Hadi \& Li (2003) [10] and Hadi (2006) [11] for the eccentrically loaded circular concrete columns that have been wrapped by sheets of the CFRP. A study that has been carried out by ElMaaddawy (2009) [12] and Song et, al. (2013) [13] have stated that with increasing the eccentricity magnitude, the strength gain as a result of the wrap of the FRP has been reduced and mid-height lateral column displacement has been increased. This has been concluded as well by AlMusawi (2012) [14] for the CFRP that has been wrapped for the reinforced self-compacting and normal concrete rectangular columns under the eccentric load. Foster \& Malik (2010) [1] have discovered that the effectiveness of the CFRP confinement is decreased in the concentrically loaded FRP confined RPC columns due to lower RPC dilation under the axial loads. For eccentrically loaded columns, CFRP has been shown efficient in the control of column failure with much straining that occurs beyond peak load. Sadeghian et, al. (2010) [15] have discovered that the stiffness of the bending and the capacity of the moment of the large-scale rectangular concrete columns have been increased by adding longitudinal FRP layers, however, the capacity of the curvature had not increase. For the configuration of the wrap with the orientation of the angle, as well as the bending stiffness and moment capacity, the capacity of the curvature was enhanced as well. Based on Mesbah \& Benzaid (2013) [3], CFRP confinement effects upon the columns' bearing and deformation capacity levels have been decreased with the increase in the strength of the concrete. Equivalent results have been stated as well by Hadi (2006) [11], Hadi \& Li (2003) [10], and Song et, al. (2013) [13]. The present paper studies the behaviors of the rectangular RC columns that have been strengthened by the composites of the CFRP under the uniaxial compression load (eccentricity $=0.5 * b$ ). The columns' efficiency has been assessed through the analysis of their ductility and load carrying capacity.

\section{Experimental Program}

Six columns were cast and then tested at labs of College of Engineering, Al-Mustansiriyah Univ., Iraq. All of the columns have been made from the concrete of normal strength. All six columns have been similar in the nominal dimensions with the square section $(100 \mathrm{~mm} \times 100 \mathrm{~mm})$ and two heights of overall height $(1200 \mathrm{~mm}$ and $1500 \mathrm{~mm})$ and effective height $(900 \mathrm{~mm}$ and $1200 \mathrm{~mm})$ respectively. All of the columns have been longitudinally reinforced with 4 steel bars with a nominal 6,10 or $12 \mathrm{~mm}$ diameter (as variable) that have been placed at each specimens' corners. All columns are reinforced with $4 \mathrm{~mm}$ stirrups from top and bottom only to tie the longitudinal 
reinforcement. The first specimen was used as a control column, while the other specimens have been strengthened by the CFRP in two ways ( 5 strip with a width of $50 \mathrm{~mm}$, full wrap). All columns were tested with an eccentricity equal to $(0.5 b)$. Table1 lists a summary of tested samples.

Table1.Specifics of R.C. Columns in this Research.

\begin{tabular}{|c|c|c|c|c|}
\hline col. Sym. & $\begin{array}{c}\mathrm{h} \times \mathrm{d} \\
\mathrm{x} \mathrm{b} \\
(\mathrm{cm})\end{array}$ & Rein. \% & $\begin{array}{c}\mathrm{W}(\mathrm{mm})^{*} \\
\text { No. }\end{array}$ & $\mathrm{Kl} / \mathrm{r}$ \\
\hline $\mathrm{S} 0-\rho_{\min }$ & $\begin{array}{c}120 \times 1 \\
0 \times 10\end{array}$ & $4 \phi 6=1.13$ & 0 & 30 \\
\hline $\mathrm{S} 5-\rho_{\min }$ & $\begin{array}{c}120 \times 1 \\
0 \times 10\end{array}$ & $4 \phi 6=1.13$ & $50 \times 5$ & 30 \\
\hline $\mathrm{S} 5-\rho_{\mathrm{mid}}$ & $\begin{array}{c}120 \times 1 \\
0 \times 10\end{array}$ & $4 \phi 10=3.14$ & $50 \times 5$ & 30 \\
\hline S5 $-\rho_{\max }$ & $\begin{array}{c}120 \times 1 \\
0 \times 10\end{array}$ & $6 \phi 12=6.78$ & $50 \times 5$ & 30 \\
\hline C5 $-\rho_{\min }$ & $\begin{array}{c}150 \times 1 \\
0 \times 10\end{array}$ & $4 \phi 6=1.13$ & $50 \times 5$ & 40 \\
\hline $\begin{array}{c}\text { Sfull - } \\
\rho_{\min }\end{array}$ & $\begin{array}{c}120 \times 1 \\
0 \times 10\end{array}$ & $4 \phi 6=1.13$ & $900 \times 1$ & 30 \\
\hline
\end{tabular}

*c, $s, \rho$ means:

C, S: Name of Column (C5 = S5: five Circumferential Strips). $\rho$ : Steel Reinforcement Ratio. W: Width of CFRP.

\subsection{Characteristics of the Materials}

Testing samples have an average of 28-day compressive strength of $34 \mathrm{MPa}$ that has been specified through the conduction of the tests on 6 cylinders. The concrete mixture of the normal strength has been utilized for making test specimens. As can be seen from table2.

Table 2. Concrete Mixture details for $\left(1 \mathrm{~m}^{3}\right)$

\begin{tabular}{lllllll}
\hline $\begin{array}{l}\text { Mix } \\
\text { No. }\end{array}$ & $\begin{array}{l}\text { W/C } \\
\text { Ratio }\end{array}$ & Mix Proportions & \multicolumn{2}{l}{$\begin{array}{l}\text { Comp. } \\
\text { Strength } \\
\text { (MPa }\end{array}$} \\
\hline & & $\left(\mathrm{Kg} / \mathrm{m}^{3}\right)$ & \multicolumn{3}{c}{$\left(\mathrm{L} / \mathrm{m}^{3}\right)$} \\
& & $\mathrm{C}$ & $\mathrm{S}$ & $\mathrm{G}$ & $\mathrm{W}$ & \\
1 & 0.4 & 400 & 600 & 1200 & 160 & 34 \\
\hline
\end{tabular}

Materials that have been utilized over the present work have been the OPC (type1), the normal weight natural sand with a maximal size of $4.75 \mathrm{~mm}$ and crushed gravel with a $12 \mathrm{~mm}$ maximal size. Steel reinforcements types that have been utilized are the deformed steel bars (6mm, 10mm and $12 \mathrm{~mm}$ ) for the longitudinal reinforcements, in addition to that; the deformed steel bars $4 \mathrm{~mm}$ have been utilized for the transverse reinforcement (ties) at only the bottom and the top. The reinforcement steel bars' tensile strength has been conducted as can be seen from table3.

Table3. Steel Bars Reinforcing Characteristics.

\begin{tabular}{lllll}
\hline No. & $\begin{array}{l}\text { Nominal } \\
\text { Diameter } \\
(\mathrm{mm})\end{array}$ & $\begin{array}{l}\text { Yield } \\
\text { Stress } \\
\text { fy (MPa) }\end{array}$ & $\begin{array}{l}\text { Ultimate } \\
\text { Stress } \\
\text { fu (MPa) }\end{array}$ & $\begin{array}{l}\text { Elongation } \\
\text { at } \\
\text { Ultimate } \\
\text { Stress (\%) }\end{array}$ \\
\hline 1 & 6 & 673 & 843 & --- \\
2 & 10 & 524 & 650 & 13 \\
3 & 12 & 478 & 636 & 12.6 \\
\hline
\end{tabular}

The fiber composite CFRP consists of two components that were installed in this work to strengthen the samples: a carbon fiber fabric layer (SikaWrap-230C) and an epoxy resin matrix (Sikadur-330).

\subsection{Strengthening Procedure}

The two materials of adhesive (white and gray) are combined together based on the manufacturer's instructions and added to a particular area of the reinforced concrete column using spoon putty on the location that are marked out for CFRP location after the surfaces have been prepared and ensured that they are dry and clean. The CFRP was then applied and handled with a $20 \mathrm{~mm}$ overlap. To better see the crack propagation, the concrete surface specimens were painted white after the CFRP construction was completed. The specimens were kept for one week before being tested.

\subsection{Columns Reinforcement Details}

In this study, deformed steel bars of $(6,10$, and 12) $\mathrm{mm}$ were used to strengthen samples with various steel reinforcement ratios. all columns have the same gross section $(100 \mathrm{~mm} \times 100 \mathrm{~mm})$ 
and have been reinforced with steel ratios $(0.0113,0.0314$ or 0.0678$)$ which are equivalent longitudinal steel bars $(4 \phi 6 \mathrm{~mm}, 4 \phi 10 \mathrm{~mm}$, or $6 \phi 12 \mathrm{~mm})$. all columns were reinforced with 4 mm stirrups from top and bottom only to bind the longitudinal reinforcement together to show the true CFRP sheet results. Figure 1 show the geometry and reinforcement details of the specimens. In addition, figure 2 depicts the CFRP distribution.
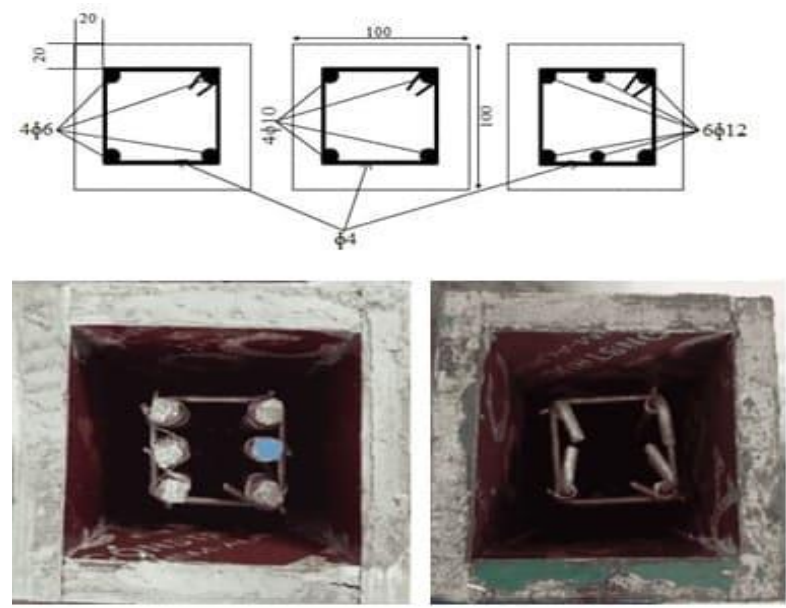

Figure1. Columns Reinforcement Details. All of the dimensions are in $(\mathrm{mm})$.

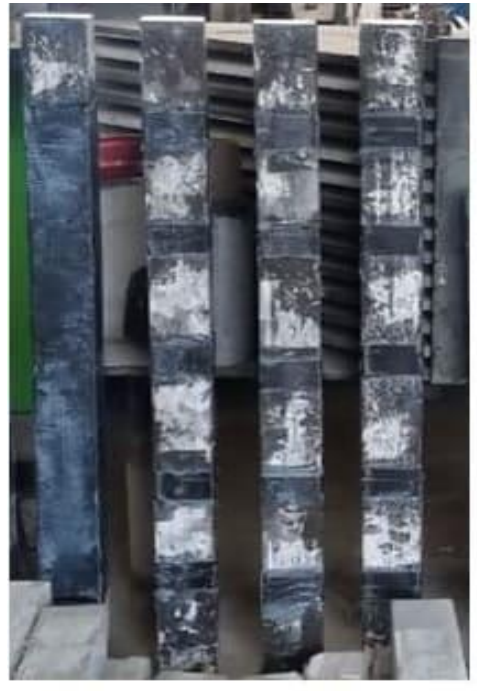

Sfull

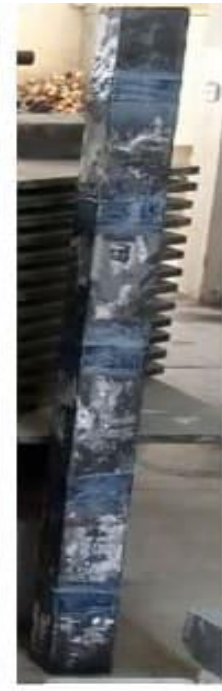

C5
Figure 2. Distribution of the CFRP.

\section{Test Measurements and Instrumentation}

The column samples are put under axial load up to ultimate states on the testing machine hydraulic universal (MFL system) with a full load capacity of $(3000 \mathrm{kN})$ at the structures laboratory in College of Engineering, Mustansiriya University. That the support point loads and dial gauges are set at the proper positions, Horizontal displacement was determined for column specimens of (0.01 $\mathrm{mm} /$ div.) precision and $(30 \mathrm{~mm})$ capability at mid-height utilizing dial gauge (ELE type). Based on the test circumstances, the upper part has been supported to be pinned and the lower part has been supported to remain fixed. The one dial gauge position has been marked at the middle of the column specimen. Figure 3 demonstrates the test set-up of the column samples.

\subsection{Load cap}

For testing the samples that are under the eccentric loading, special system of loading head has been designed, manufactured and made of high strength steel that have been put at the ends of the column. It includes two fundamental parts: a $30 \mathrm{~mm}$ thick steel couple plate may be moved, then fixed afterwards on anther with the bolts sitting on the ends of the column cube, and circular roller as the knife load with a diameter of $40 \mathrm{~mm}$. It may be moved then fixed afterwards along the plate axis for achieving needed eccentricity at a distance that has been set from the column cross section center as depicted in figure4.
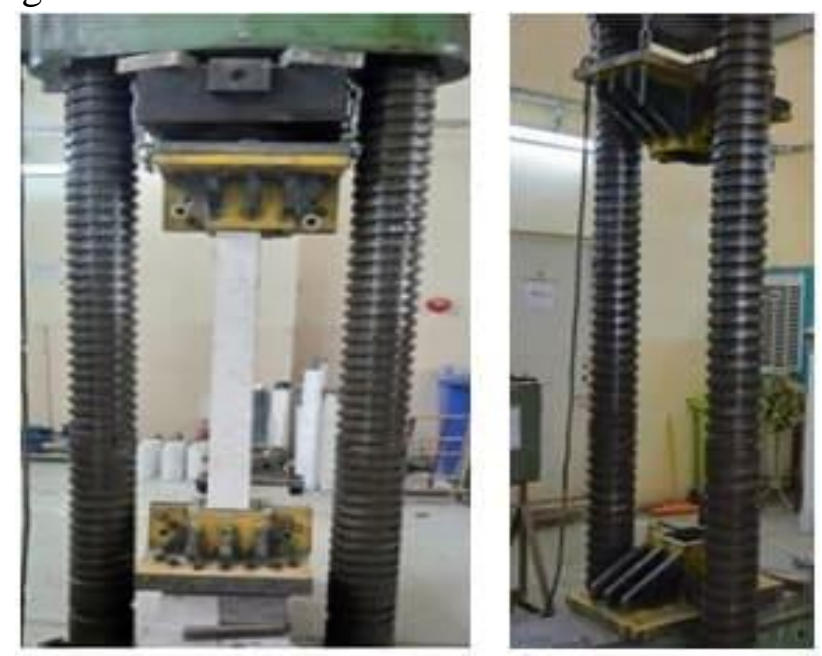

Figure 3a. Testing Setup of the Column Specimens 


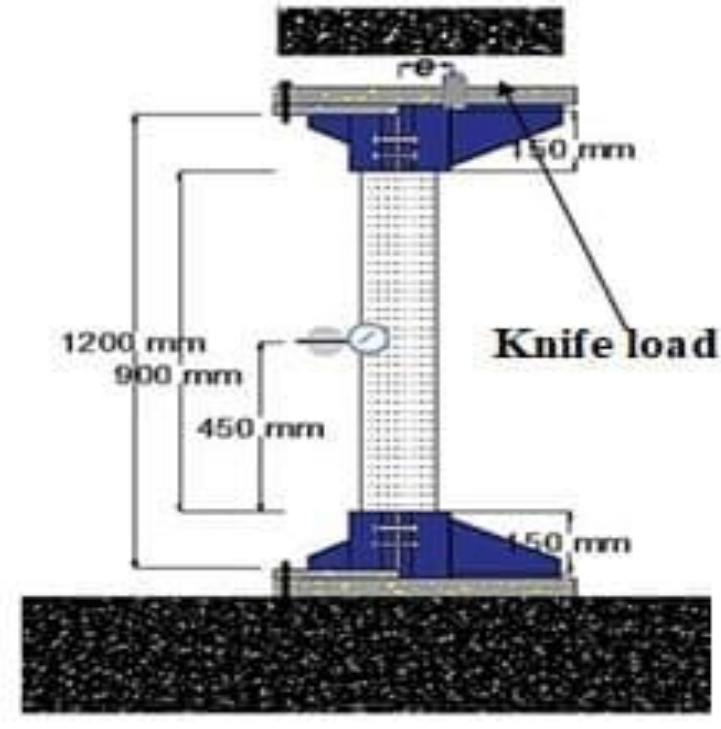

Figure 3b. Testing Setup of the Column Specimens

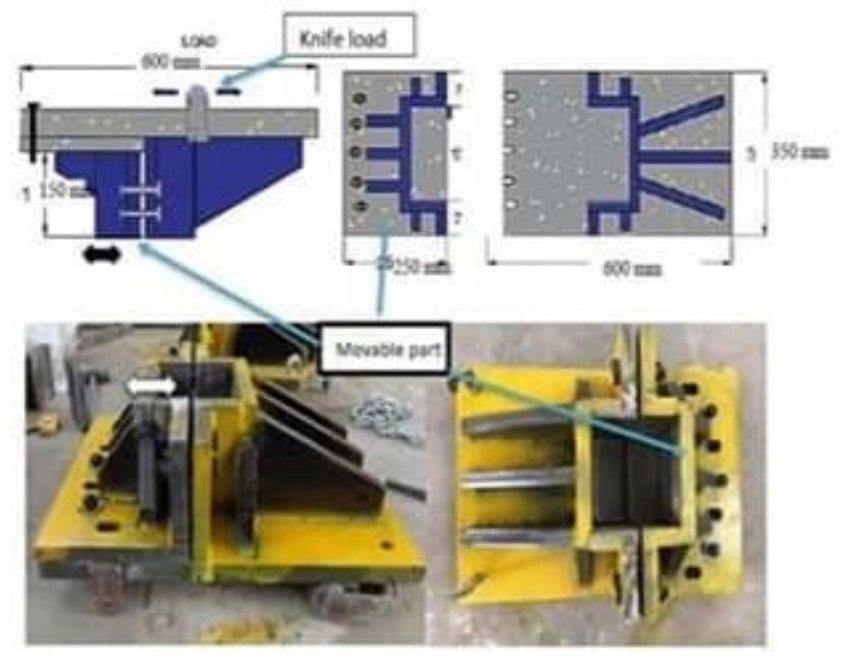

Figure 4. Load caps.

\section{Results and Discussions}

Each specimen has been tested and ultimate load values as well as corresponding lateral RC column displacements have been recorded throughout eccentric compression load that has been applied, based upon slenderness ratio with the distribution of the CFRP and different ratio of the steel reinforcement. The results of the tests for each specimen have been listed in Table4. After each (5sec.) the RC columns' load increment has been checked for the cracks and any of the potential marks of failure.
Table4. Testing Results and Details of columns up to the

\begin{tabular}{|c|c|c|c|c|}
\hline $\begin{array}{l}\text { Col. } \\
\text { sym. }\end{array}$ & $\begin{array}{c}\text { Ultimate } \\
\text { load } \\
\mathrm{Pu}(\mathrm{kN})\end{array}$ & $\begin{array}{c}\text { Crack } \\
\text { Load } \\
\text { Pcr } \\
(\mathrm{Kn})\end{array}$ & $\begin{array}{c}\% \\
\text { Increase } \\
\text { in } \mathrm{Pu}\end{array}$ & $\begin{array}{c}\text { Displacement } \\
\text { at mid- } \\
\text { height } \\
(\mathrm{mm})\end{array}$ \\
\hline $\begin{array}{l}\mathrm{S} 0 \text { - } \\
\rho_{\min }\end{array}$ & 200 & 66 & Ref & 1.25 \\
\hline $\begin{array}{l}\text { S5 - } \\
\rho_{\min }\end{array}$ & 230 & 76 & 15 & 2.1 \\
\hline $\begin{array}{l}\text { S5- } \\
\rho_{\text {mid }}\end{array}$ & 265 & 85 & 32.5 & 2 \\
\hline $\begin{array}{l}\text { S5 - } \\
\rho_{\max }\end{array}$ & 280 & 97.5 & 40 & 1.88 \\
\hline $\begin{array}{l}\mathrm{C} 5 \text { - } \\
\rho_{\min }\end{array}$ & 218.5 & 71 & 9.25 & 2.95 \\
\hline $\begin{array}{l}\text { Sfull } \\
-\rho_{\min }\end{array}$ & 320 & 103 & 60 & 4.57 \\
\hline
\end{tabular}

The tested column failure modes and their outcomes are depicted in the graphs, curves, and bar charts shown in figures $(5,6,7,8,9$, and 10). It was discovered that confining columns with CFRP causes an increase in loading of columns. In the case where 5 strips of CFRP with a width of $5 \mathrm{~cm}$ are confined and distributed symmetrically along a column, the column's strength increases by around $15 \%$ when compared to a reference column. However, for the columns that have the full CFRP, the increase in load capacity is nearly $60 \%$ when compared to the reference columns, besides improving column ductility in both cases.

The slenderness ratio effects, on the other hand, provided rational effects, as increasing the slenderness ratio led to a reduction in the column load capacity, and these results also demonstrated that confining columns with CFRP improved the results for all slenderness ratios as shown in figure 9.

Also, the effects of steel reinforcement ratio on the behavior of tested columns. Increases in the steel ratio have a noticeable effect on column stiffness and ductility, resulting in an improvement in both first cracking and ultimate 
loads, as well as a substantial delay in crack progression and decrease in displacement. Clearly, as the steel ratio was increased from $1.13 \%$ to $3.14 \%$ and $6.78 \%$, the load capability of the columns increased, as a result of increased stiffness and ductility caused by raising the major steel ratios as shown in figure 10.
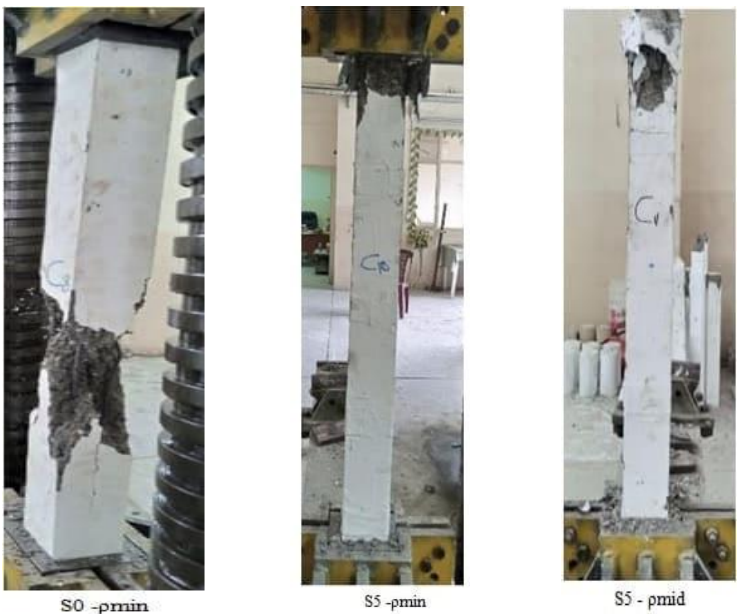

Figure 5a. Crack Patterns for all Columns at Failure

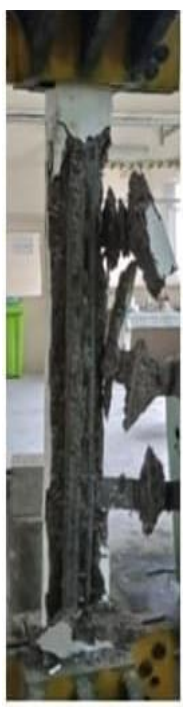

S5-pmax

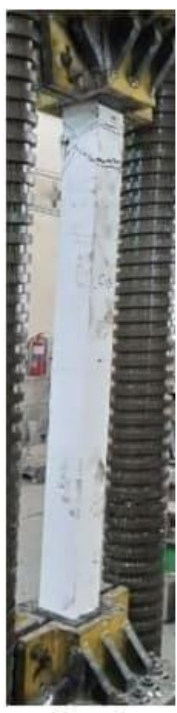

C5 - pmin

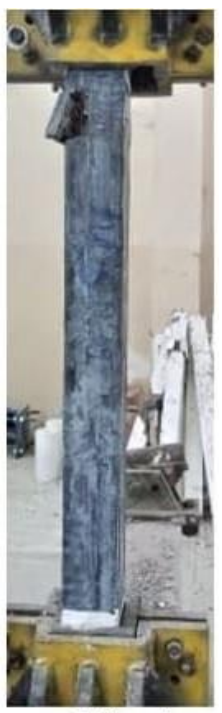

Sfull - pmin
Figure 5b. Crack Patterns for all Columns at Failure

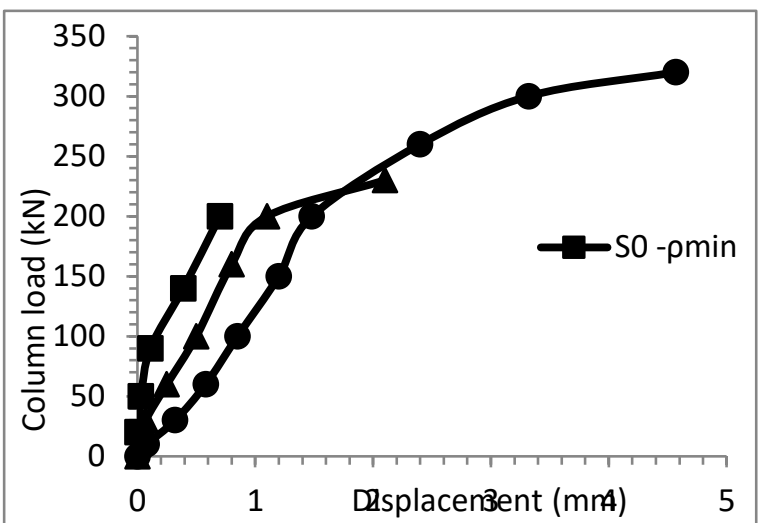

Figure 6.Load-Displacement for Columns different CFRP Distributions.

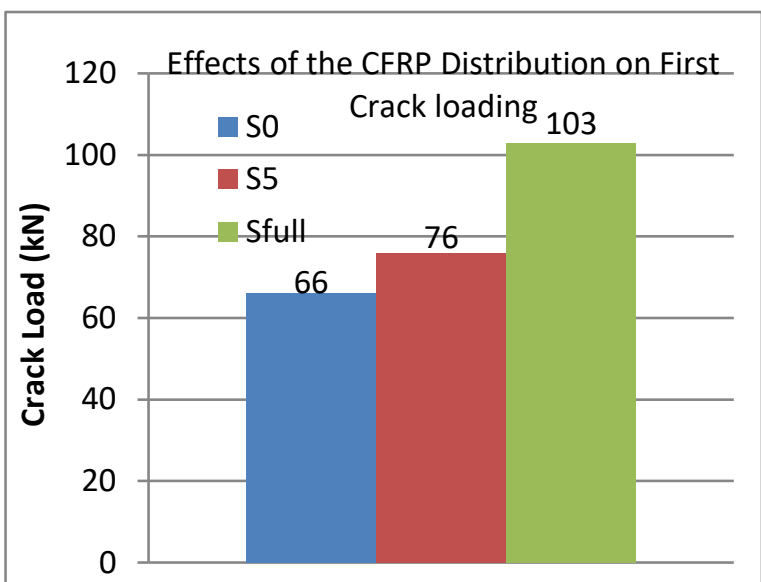

Figure 7a. Bar chart of the effects of the Distribution of the CFRP on First Crack Loading

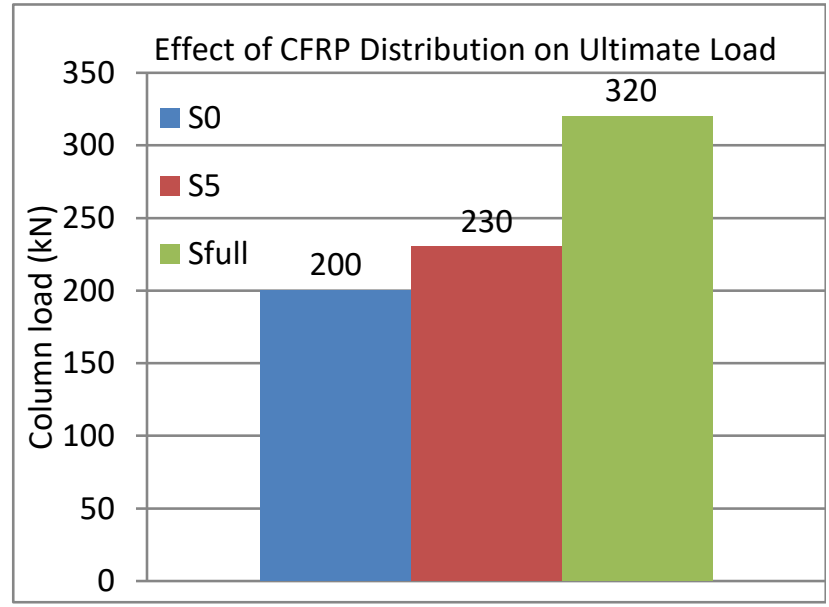

Figure 7b. Bar chart of the effects of the Distribution of the CFRP on Ultimate Load. 

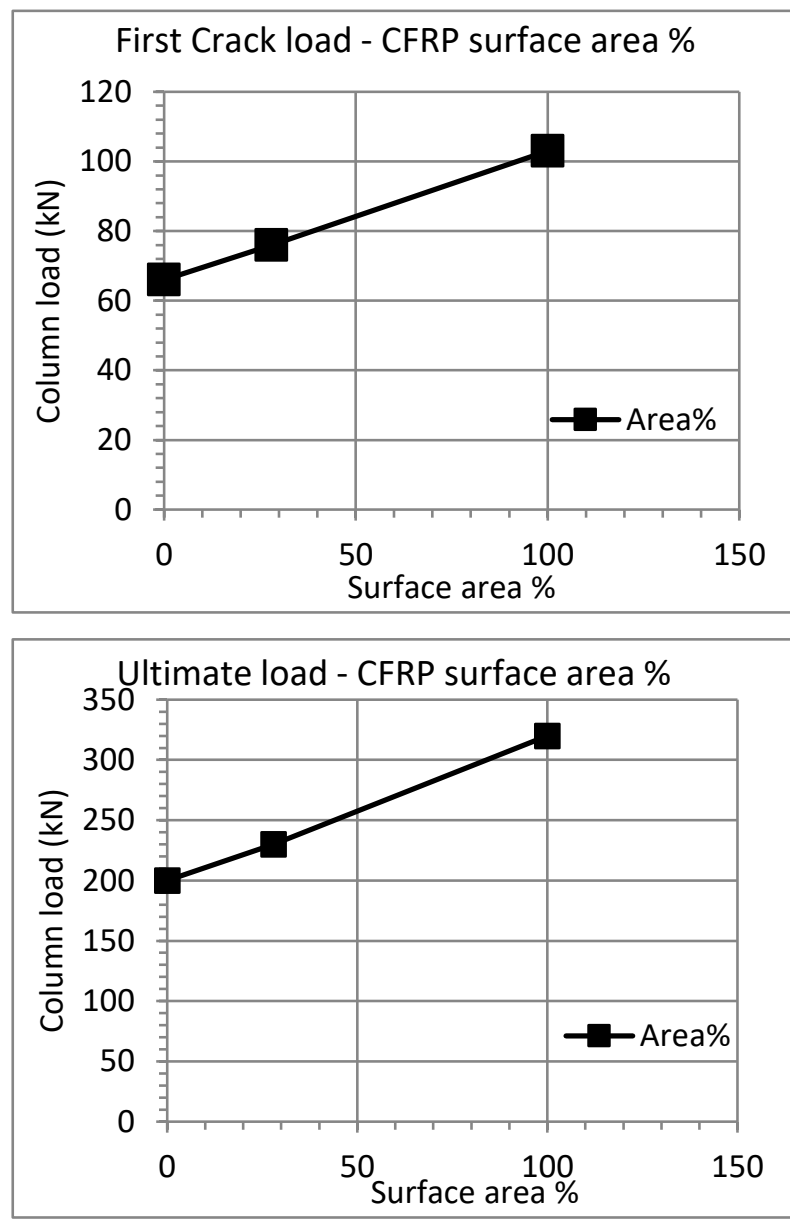

Figure 8. Effect of CFRP Surface Area Ratio on First Crack and Ultimate Loads.

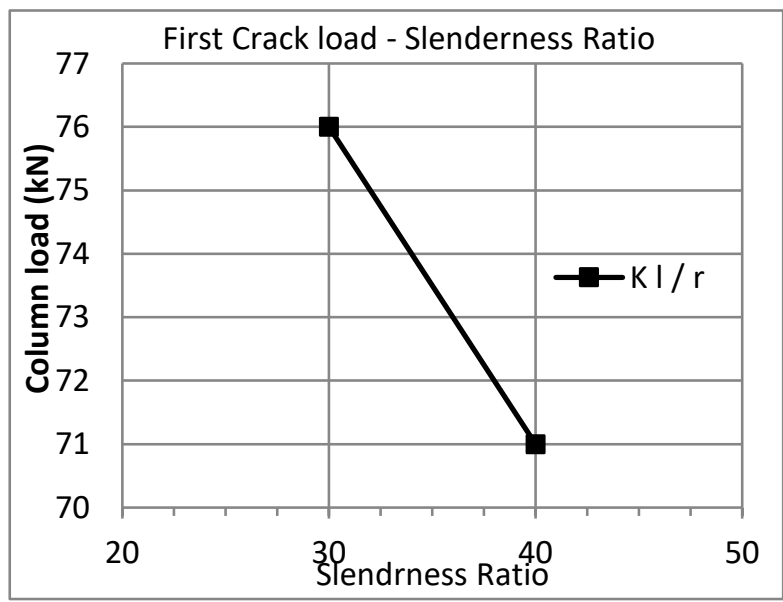

Figure 9a. Effect of Slenderness Ratio on First Crack

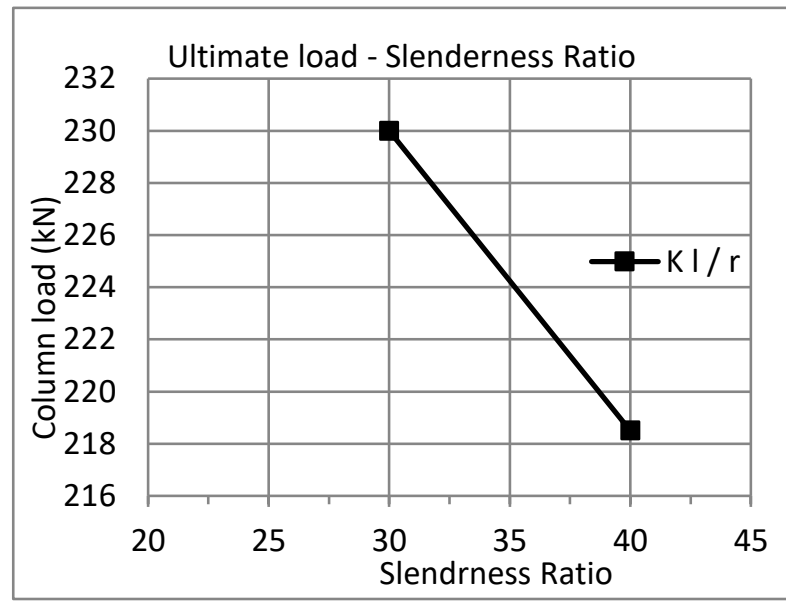

Figure 9b. Effect of Slenderness Ratio on Ultimate Load.
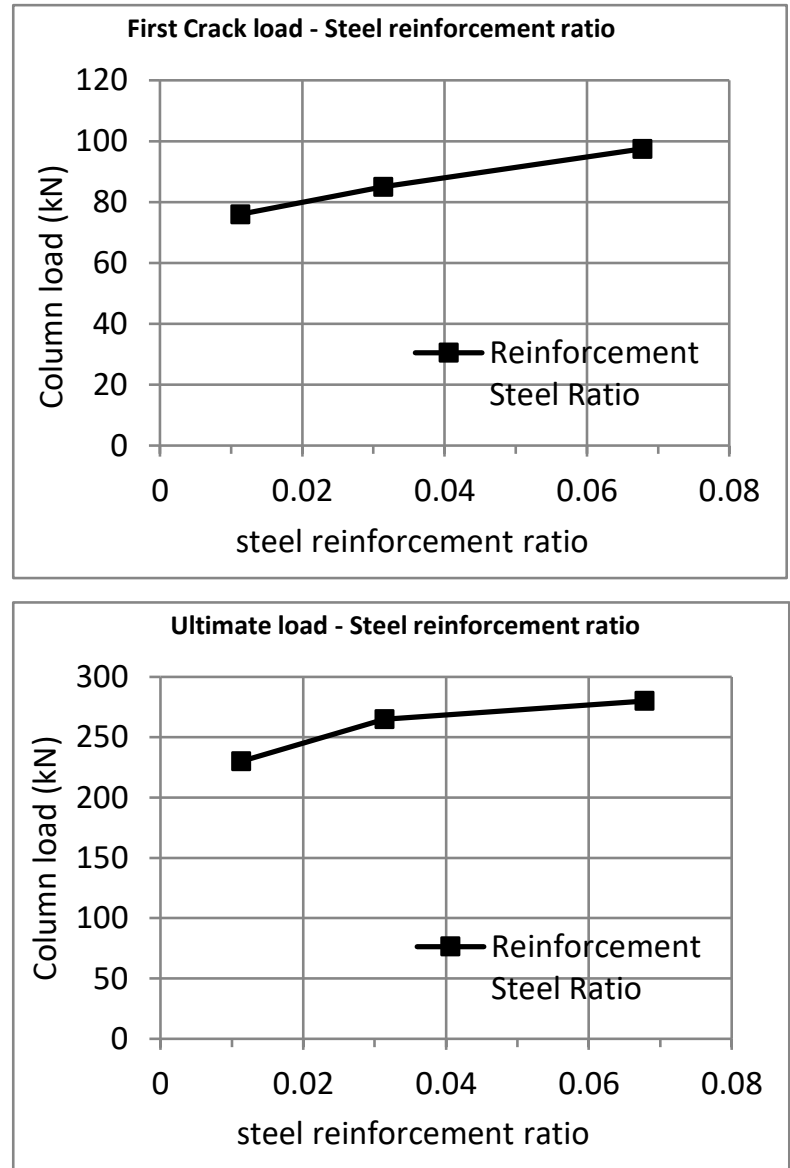

Figure 10. Effect of Steel Reinforcement Ratio on First Crack Load and Ultimate Load.

\section{Conclusions}

The conclusions below may have been obtained from this research: 
1- The confinement of columns with CFRP increased the load strength of columns by $60 \%$.

2- The load strength of columns has been reduced with the increase in the slenderness ratio, however, the results of confined columns with CFRP improved.

3- Increasing the steel reinforcement ratio for columns improve the stiffness, the performance of columns and increases both crack load and ultimate load of tested specimens. Increasing the steel ratio from $(1.13 \%$ to $3.14 \%$ and $6.78 \%$ ) for columns tested under the eccentric loading the ultimate load was increased about $(32.5 \%$ and $40 \%)$, respectively. For the same level of CFRP strengthening (five strips).

\section{Acknowledgement}

The author would like to acknowledge the department of Civil Engineering, College of Engineering, Mustansiriyah University for their encouragement and support.

\section{Conflict of Interest}

The authors confirm that the publication of this article causes no conflict of interest.

\section{Abbreviations}

$\begin{array}{ll}\text { b } & \text { Width of Cross Section } \\ \text { CFRP } & \text { Carbon Fiber Reinforced Polymer } \\ \mathrm{d} & \text { Depth of Cross Section } \\ f c^{\prime} & \text { Cylinder Compressive Strength of } \\ & \text { Concrete } \\ \text { FRP } & \text { Fiber Reinforced Polymer } \\ \text { fu } & \text { Ultimate Stress of Steel } \\ \text { fy } & \text { Yield Stress of Steel } \\ \text { G } & \text { Gravel } \\ \text { h } & \text { Height of Cross Section } \\ \text { k } & \text { Effective Length Factor } \\ l u & \text { Unbraced Column Length } \\ \mathrm{MPa} & \text { Mega Pascal }\left(\mathrm{N} / \mathrm{mm}^{2}\right) \\ \mathrm{Pcr} & \text { Cracking Load }\end{array}$

$\begin{array}{ll}\mathrm{Pu} & \text { Ultimate Load } \\ \mathrm{RC} & \text { Reinforced Concrete } \\ \mathrm{r} & \text { Radius of Gyration } \\ \mathrm{S} & \text { Sand } \\ \mathrm{W} & \text { Water } \\ \rho_{\text {min }} & \text { Minimum Steel Ratio } \\ \rho_{\text {mid }} & \text { Intermediate Steel Ratio } \\ \rho_{\text {max }} & \text { Maximum Steel Ratio }\end{array}$

\section{References}

1- Malik, A. and Foster, S. (2010). "Carbon Fiber-Reinforced Polymer Confined Reactive Powder Concrete Columns Experimental Investigation". ACI Structural Journal, Vol.107, No. 3, pp. 263271.

2- Parvin, A. and Brighton, D. (2014). "FRP Composites Strengthening of Concrete Columns under Various Loading Conditions". Polymers, Vol. 6, pp. 10401056.

3- Benzaid, R. and Mesbah, H. (2013). "Circular and Square Concrete Columns Externally Confined by CFRP Composite: Experimental Investigation and Effective Strength Models". Fiber Reinforced Polymers - The Technology Applied for Concrete Repair, Chapter 6, pp.167-201.

4- Amir, A., Naseer, A. and Azam, O. (2013). "Strengthening of Existing Building Column Using FRP Wrap \& GI Wire Mesh", International Journal of Scientific \& Engineering Research, Volume 4, Issue 5, pp. 211-216.

5- Olivova, K. and Blicik, J. (2009). "Strengthening of Concrete Columns with CFRP", Slovak Journal of Civil Engineering, Vol.1, pp. 1-9.

6- Setunge, S., et al. (2002). "Review of Strengthening Techniques Using Externally Bonded Fiber Reinforced 
Polymer Composites". CRC Construction Innovation, Report 2002-005-C-01, pp. 59.

7- Chowdhury, E. (2009). "Behavior of Fibre Reinforced Polymer Confined Reinforced Concrete Columns under Fire Condition". $\mathrm{PhD}$ thesis, Queen's University, Ontario, Canada, pp.235.

8- Rocca, S., Galati, N. and Nanni, A. (December 13-15, 2006). "Large-Size Reinforced Concrete Columns Strengthened with Carbon FRP: Experimental Evaluation". Third International Conference on FRP Composites in Civil Engineering, Florida, USA, pp. 4.

9- Parvin, A. and Wang, W. (August 2001). "Behavior of FRP Jacketed Concrete Columns under Eccentric Loading". ASCE Journal of Composites for Construction, Vol. 5, No.3, pp.146-152.

10- Li, J. and Hadi, M. (2003). "Behaviour of externally confined high-strength concrete columns under Eccentric loading". Composite Structures, Vol. 62, pp.145-153.

11-Hadi, M. (2006). "Behaviour of FRP wrapped normal strength concrete columns under eccentric loading". Composite Structures, Vol. 72, pp.503-511.

12- .El Maaddawy, T. (2009). "Strengthening of eccentrically loaded reinforced concrete columns with Fiber-reinforced polymer wrapping system: Experimental investigation and analytical modelling". ASCE Journal of Composites for Construction, Vol.13, pp.13-24.

13-Song, X., Gu, X., Li, Y., Chen, T.and Zhang, W. (2013). "Mechanical behavior of FRP strengthened concrete columns subjected to concentric and eccentric compression loading". ASCE Journal of Composites for Construction, Vol. 17, pp. 336-346.
14- Al-Musawi, A. (2012). "Experimental Study of Reinforced Concrete Columns Strengthened with CFRP under Eccentric Loading". M. Sc. Thesis, Mustansiriyah University, Baghdad, Iraq, pp.120.

15-Sadeghian, P., Rahai, A. and Ehsani, M. (2010). "Experimental study of rectangular $R C$ columns Strengthened with CFRP composites under eccentric loading". ASCE Journal of Composites for Construction, Vol. 14, pp. 443-450. 